\title{
Retratos da solidão: sofrimentos e moralidades femininas na velhice
}

\author{
Raphael Bispo \\ Doutor em Antropologia Social (Museu Nacional/UFR)) \\ Pesquisador do CESAP/IUPERJ/UCAM \\ Rio de Janeiro, Rio de Janeiro, Brasil \\ raphaelbispo83@gmail.com
}

\begin{abstract}
Resumo Durante os anos 1970, um conjunto de dançarinas sensuais, as chacretes, ganhou destaque na televisão. Este artigo analisa a trajetória de vida da primeira geração dessas mulheres, hoje com mais de 60 anos de idade. O objetivo desta pesquisa etnográfica é debater suas experiências de solidão. Tal emoção é uma temática constante e, ao mesmo tempo, quase ausente na literatura especializada sobre o envelhecimento. Tal paradoxo se impõe porque enquanto se valorizaram estudos sobre a "vida ativa" dos idosos, a solidão emergiu como tema a ser confrontado, portanto pouco pesquisado. Assim, este texto procura contribuir para uma etnografia da solidão feminina na velhice. Estar sozinha faz sentido a partir de determinadas condições sociais específicas, principalmente quando se notam certos marcadores sociais da diferença, como idade, gênero, sexualidade e classe diretamente articulados a tal vivência emocional.
\end{abstract}

Palavras-chave: gênero, sexualidade, envelhecimento, solidão, mundo artístico.

$\mathrm{P}$ ode-se dizer que a temática da solidão é algo constante e ao mesmo tempo quase ausente na literatura especializada dedicada ao envelhecimento. É um assunto que sempre tangencia reflexões sobre o envelhecer, sem necessariamente tornar-se um ponto de atenção especial. Tal paradoxo instala-se por diversas razões. A princípio, poderíamos pensar que um livro como $A$ solidão dos moribundos, do alemão Norbert Elias (2001), esgotaria qualquer iniciativa de outros autores em prol de uma reflexão mais sistemática sobre o indivíduo solitário, justamente por ser um texto impactante e escrito por um intelectual renomado. No entanto, se atentarmos melhor para esse ensaio de Elias (2001), perceberemos que se trata muito mais de um trabalho sobre pessoas no leito de morte e seus rompimentos afetivos com entes queridos do que propriamente uma reflexão sobre geração, final da vida e (des)enlaces sociais. Afinal, moribundos não são necessariamente velhos. ${ }^{1}$

$\mathrm{Na}$ verdade, é possível afirmar que por causa das representações sociais sobre a velhice, fortemente associadas a estigmas ligados à decadência física e ao isolamento, a solidão tornou-se um tema mais a ser confrontado do que pesquisado pelos especialistas. Valorizaram-se desde os anos 1980, nas ciências sociais brasileiras, por exemplo, trabalhos empíricos sobre a "vida ativa" dos idosos e suas redes de sociabilidade, principalmente de mulheres. As etapas mais avançadas da vida são interpretadas como momentos privilegiados para novas conquistas

1. Além desse trabalho de Elias (2001), que é acompanhado por outro ensaio intitulado Envelhecer ou morrer, identifiquei reflexões mais detalhadas sobre a solidão na velhice nos trabalhos de Thompson, Itzin e Abenstern (1991), Peixoto (1997), Caradec (2004) e Pais (2006). 
no âmbito dos afetos, guiadas pela busca do prazer, da satisfação e da realização pessoal. ${ }^{2}$

Seguindo aquilo que Debert e Brigeiro (2012, p. 6) relatam, ao buscarem situar historicamente os discursos contemporâneos críticos da gerontologia/ geriatria acerca do "mito da velhice assexuada", que o que está em jogo nesses trabalhos precursores é também um conjunto de discursos empenhados em rever estereótipos negativos da velhice, derrubando assim o que poderíamos chamar, parafraseando o que dizem os autores, de "o mito da velhice solitária". Nesse sentido, os bailes e universidades "da terceira idade", os clubes para aposentados e as conversas em praças, esquinas e bares entre "pessoas de idade" surgiram como lugares e momentos oportunos a fim de se acompanhar os idosos "em ação", principalmente nos estudos com marcas antropológicas/etnográficas.

A solidão tangencia uma ou outra passagem dessas pesquisas, sempre abordada de maneira um tanto superficial, emergindo como tópico a fim de se criticar o estereótipo do velho solitário. Peixoto (1997, p. 150), por exemplo, atentou em sua pesquisa para as "estratégias de fuga da solidão" de idosos no Rio de Janeiro, com o intuito de mostrar aos leitores o quanto a inatividade da aposentadoria, ou mesmo as situações de viuvez, é muitas das vezes compensada por um dinamismo social, e não por um afastamento da sociedade e sensações "terríveis" de solidão.

Portanto, o objetivo central deste artigo é estimular uma reflexão mais aprofundada sobre tal tema tão "ausente-presente" na literatura especializada sobre o envelhecimento: a solidão. Certamente, não propõe-se aqui criar um contraponto a fim de confirmar aquilo que essas pesquisas souberam muito bem desanuviar, ou seja, o senso comum de que velhos são solitários e que sofrem por isso, mas, pelo contrário, busca-se demonstrar neste ensaio que a solidão é uma experiência emocional repleta de vicissitudes e ambiguidades, passível de ser vivida em qualquer etapa do ciclo da vida de uma pessoa, e que a idade (seja ela qual for) é, sim, um marcador social da diferença que opera como fator importante para certas sensa- ções particulares de solidão e desentranhamento do mundo.

Ao longo do texto, são apresentados dados etnográficos coletados entre 2010 e 2011 e relativos à solidão feminina na velhice que pude acompanhar durante minha pesquisa de campo com um segmento particular de artistas populares, as chacretes, antigas dançarinas de televisão. ${ }^{3} \mathrm{O}$ objetivo inicial de minha pesquisa de doutorado era analisar a trajetória de vida da primeira geração de chacretes, hoje com mais de 60 anos de idade. Ao longo da pesquisa de campo, porém, pude acompanhar variadas experimentações da sensação de estar só por parte de algumas dessas dançarinas. Os sofrimentos relativos a estar sozinha no mundo pouco compunham com as falas mais ordinárias e muito menos dominavam por completo a vida dessas mulheres. Tais sensibilidades, mesmo de grande dimensão e influência em seus cotidianos, ocupavam as periferias do dizível e os cantos mais obscuros daquilo que é dignamente apresentável ao outro.

Sendo assim, a partir da construção do retrato da solidão da chacrete Joana Meriti ${ }^{4}$ - com base na forma discursiva "confessional" como ela expressa essa emoção - pretendo, por meio da ideia do retrato, do portrait, contextualizar a experiência emocional dessa "velha solitária", pensando o quanto essa vivência só faz sentido a partir de determinadas condições sociais. Isso porque a solidão não existe em estado puro, muito menos na velhice. A ideia de retrato remete justamente ao foco em um determinado momento de uma trajetória de vida, dando espaço para se pensar nas transformações dessa emoção ao longo do tempo e nas situações sociais e morais em que ela se expressa.

Em termos metodológicos, procuramos apresentar aqui as dimensões da vida solitária, tendo como base a proposta de Abu-Lughod e Lutz (1990) acerca de uma "perspectiva contextualista das emoções". O que se pretende seguindo tal ideia é compreender o fenômeno da solidão nas situações sociais específicas em que ele se expressa, atentando mais para as práticas do que para o significado das emoções em

\footnotetext{
2. Essa constatação já podia ser verificada em Lins de Barros (1981, 1987). Motta (1998), Debert (1999), Peixoto (1997, 2000), Alves (2004) e Goldenberg (2008) percebem algo semelhante, mesmo partindo de experiências de campo com segmentos femininos da população bastante distintos.

3. Durante os anos 1970 e 1980, as chacretes ganharam destaque na televisão. Além de auxiliar o apresentador Abelardo Barbosa, o Chacrinha, em programas de auditório, elas compunham paralelamente um crescente mercado erótico, estendendo suas atuações para as boates-revistas, a pornochanchada, os ensaios sensuais e a prática de programas de luxo. Chacrinha é considerado um dos maiores apresentadores da televisão brasileira. Sua trajetória teve início no rádio, mas o sucesso maior foi mesmo quando começou a comandar programas de auditório como a Buzina do Chacrinha e a Discoteca do Chacrinha. Chacrinha morreu no ano de 1986. Para mais detalhes sobre as carreiras artísticas das chacretes, ver: Bispo (2012,2013).
}

4. Os nomes apresentados neste artigo são fictícios. A pesquisa de campo foi realizada ao longo dos anos de 2010 e 2011 . Além da realização de entrevistas estruturadas com as chacretes, por meio de um roteiro, buscou-se uma maior aproximação com essas mulheres, participando de seus cotidianos e de suas atividades artísticas contemporâneas. Para concretizar essa experiência mais profunda com as antigas dançarinas, a pesquisa baseou-se nas histórias e vivências de cinco chacretes. Buscou-se reduzir o escopo da pesquisa em prol de uma maior intimidade e profundidade analítica. 
si mesmo. Isso porque Abu-Lughod e Lutz (1990, p. 6), ao defenderem o valor discursivo das emoções, sugerem que se deve ir além das relativizações das falas emotivas típicas do empreendimento da "cultura como texto" geertziana e adotar uma perspectiva mais pragmática e dinâmica sobre elas. Os sentimentos são compreendidos pelas autoras como elementos da linguagem social e, portanto, fundamentalmente formulados a partir de certas práticas e ideologias que regem uma determinada sociedade. Isso significa dizer que as emoções estão presentes nas negociações de significados entre os sujeitos sobre os seus próprios cotidianos, nas dinâmicas locais de poder que regem uma determinada sociedade, bem como na interferência dos direitos e moralidades ali vigentes, o que deve ou não ser dito, entre outras instâncias específicas de uma vida social.

Constantemente, Abu-Lughod e Lutz (1990) recorrem à noção de discurso de Foucault para elucidar essa perspectiva. O foco de preocupações não é com o que é dito no discurso emotivo em si, e sim com o que é esse discurso, o que ele faz e como é formulado. A atenção está na prática do discurso emotivo, e não no significado advindo de uma interpretação dele (algo recorrente na perspectiva mais interpretativa da cultura). Se a discursividade são falas que formam aquilo sobre o que se fala, ela não mantém com as emoções uma relação de referência, como se fosse algo externo aos sentimentos; pelo contrário, compõem, dão vida e formam diretamente a dimensão subjetiva dos sujeitos. "Pode-se dizer que as emoções são criadas na, e não modeladas pela fala no sentido de que são postuladas como uma entidade na linguagem, onde o seu sentido para o ator social também é elaborado" (Abu-Lughod; Lutz, 1990, p. 12. Grifos do original).

Sendo assim, a solidão entre algumas chacretes não é aqui entendida como algo estanque e de sentido único, uma abstração despida das vivências concretas, mas, na verdade, como uma experiência emocional dependente do contexto em que os discursos sobre ela são efetuados, na medida em que apontam para as negociações da vida realizadas pelas chacretes e as relações que elas estabelecem com a sociedade envolvente. Foge-se com isso de uma essencialização dessa experiência emocional, para pensá-la como um sentimento extremamente diversificado, vivido de formas muito diferentes - até mesmo discrepantes - e que se atualiza justamente na diversidade de experiências possíveis. A solidão é perceptível a partir da apreensão de suas múltiplas facetas cotidianas.

Por fim, é preciso levar em conta, nessa ideia do retrato da solidão, que as emoções convivem com certas realidades, seguindo a combinação de diferentes marcadores sociais que, quando em intersecção, operam gerando diferenças e até mesmo construindo desigualdades. Se Lutz (1998, p. 72; 1990, p. 69) já disse que qualquer discurso sobre emoções é também, pelo menos implicitamente, um discurso sobre gênero ("engenderedemotion"), podemos afirmar que as emoções são também discursos sobre a idade, a classe social, a "raça"/etnia, a sexualidade etc. Logo, ao abordar a solidão entre as chacretes, é preciso considerar de imediato o fato de elas serem mulheres heterossexuais, de terem mais de 60 anos de idade, de possuírem ou não uma vida sexual ativa, de serem de classe popular e terem a família como uma referência básica em suas vidas, entre outras considerações. Dessa forma, podemos tecer com maior eficiência, mesmo que de uma maneira fragmentada e incompleta, uma teia de reflexões sobre as diferentes maneiras de se sentir solitária na contemporaneidade, analisando detalhadamente o contexto dos enlaces e desenlaces que produzem essa emoção a partir de uma trajetória de vida, no caso deste artigo, de Joana Meriti.

\section{Morar sozinha, ou das proximidades que afastam}

O que pode ser feito quando os dias parecem mais longos do que de costume? Quando, depois de acordar, a primeira sensação é a de um "vazio profundo", seguida de uma letargia desconfortante, mas também bem-vinda porque amaina os ânimos, deixa-os sob controle já bem cedo? A cama de Joana é o próprio sofá da sala. Ela abriu mão faz tempo de ter uma cama no lar, não precisando nem mesmo de um quarto como aposento. Já desistiu dessas coisas. É sala, cozinha e banheiro, apenas. Não sente a necessidade de grandes luxos, tudo isso basta para viver. O espaço doméstico não é um estímulo à ação. Vai-se da sala para a própria sala.

O bairro onde mora Joana é o mesmo desde a infância. Ele é residencial, de maciça presença de operários e pequenos comerciantes, com casas modestas, umas coladas nas outras. As ruas são estreitas e garantem uma sociabilidade típica das regiões mais periféricas dos centros urbanos. Boa parte dos vizinhos se conhece há anos, fala entre si e estabelece algum tipo de convivência.

De seus atuais 63 anos de vida, Joana passou pelo menos 50 deles por ali. Mora hoje sozinha em um "puxadinho" em cima de sua antiga residência, cedida ao filho que acabou de se casar. Boa parte de seus parentes próximos já faleceu. Por estar ali há tanto tempo, é uma figura extremamente conhecida, a "artista" do bairro, e todos possuem algum apreço e carinho por ela. Na verdade, por conta de seu passado artístico e de um ethosfeminino destoante da maioria 
das mulheres da área, Joana criou, com o passar dos anos, fama de "exótica", "diferente". Dessa forma, todos os que a cercam olham-na como uma exceção e sentem por ela admiração, respeito e, diria, até mesmo fascínio. Ao mesmo tempo, como qualquer exceção à regra, essa economia geral dos sentimentos pode despertar impaciência, irritação e mesmo ofensas. Não é à toa que alguns rapazes dos bares chegam a se referir a ela jocosamente como "velha assanhada" ou "maluca", da mesma forma que demonstram preocupação e carinho quando falam da "mulher sozinha do 49" ou da "velhinha da esquina".

Assim, em um bairro cuja sociabilidade parece ser quase uma obrigação, Joana sente-se sozinha e prefere a letargia permitida pelo sofá-cama, mesmo rodeada por amigos e conhecidos de longa data. Ela fecha-se quase ostensivamente, inclusive em família, em um isolamento ao mesmo tempo difícil e prazeroso que a velhice só veio acentuar. Passou a morar sozinha recentemente, depois que o filho único instalou-se na casa mais espaçosa debaixo da sua, por conta de seu casamento. Mas já se sentia solitária em sua companhia quando fora "deixada de lado" pelo marido alguns anos antes, como costuma dizer. Diferentemente de algumas mulheres, para as quais morar só é indicativo de autonomia, desejo de privacidade e mesmo sucesso e prestígio na carreira profissional (Martins, 2010, p. 27), para Joana, essa condição é fruto de um constrangimento. Morar sozinha não é uma opção, mas uma condição indesejada, negativa. Foi na velhice que viver só ganhou contornos agonísticos.

Com relação ao seu filho, o sentimento da solidão é certamente recente, sentido um tanto como passageiro, pontual. Algumas rusgas com a nora dificultam seu trânsito pela residência do casal. Ela também o tem visto muito pouco porque o rapaz trabalha bastante. Não se trata propriamente de um esquecimento da mãe, pelo menos por agora. Joana sabe que, se precisar, quando suas "pernas pararem", o filho não irá abandoná-la e lhe dará todo o suporte necessário.

Mas outra dimensão desse distanciamento do mundo liga-se também a certo desconforto de Joana em estar junto a pessoas do sexo feminino. A chacrete não tem muitas amigas. Marília, trinta anos mais nova do que ela, costuma aparecer em sua casa na parte da tarde para assistirem a novelas juntas. Foi a única amiga que conheci durante dois anos de pesquisa. Existem outras duas mulheres que a chacrete costuma mencionar como "colegas", mas que raramente aparecem por lá. Isso porque as mulheres são, na maioria das vezes, aquelas com quem Joana mais costuma desentender-se e mesmo entrar em conflito. As mulheres são "podres", na visão de Joana.

Entre as chacretes de um modo geral, sempre foi bastante comum ouvi-las reclamar das mulheres, esse termo vago e impreciso que, mesmo assim, desperta paixões com intensidade entre todas. É claro que a maioria não chega ao extremo de qualificar as mulheres como pessoas "podres", e mantem algumas amigas próximas e fiéis. No entanto, sempre as ouvi tecer inúmeras críticas a esse coletivo, fazendo uso de termos como "invejosas", "despeitadas", "falsas" e "traidoras". Elas têm o costume de aconselhar os mais próximos, principalmente a parentela feminina, de que as mulheres em sua maioria não são confiáveis e voltam-se contra elas diante da menor provocação. A falsidade feminina explicar-se-ia porque as mulheres sempre se sentem ameaçadas diante de outra "muito mais bonita" do que elas.

Joana, por sua vez, parece elevar esses conflitos a um patamar ainda mais radical: deseja socializar-se o mínimo possível com mulheres. Ela sente a "mulherada" em cada esquina que passa. Em alguns momentos, o "grupo" parece juntar-se para perturbá-la ao "mexer com ela" nas ruas: "cafona", "brega", "prostituta", "piranha" e "vagabunda" são acusações das quais diz ser alvo. As palavras nunca são diretas. Surgem no meio de bochichos, conversas entrecortadas e risinhos. Ah! Os risinhos femininos... Como eles deixam Joana enfurecida e, ao mesmo tempo, triste, muito triste.

A fama de "roubar homens" de Joana é antiga. As acusações ganharam mais consistência nas redondezas nos últimos anos, quando começou a morar sozinha, logo após a separação do último marido. Foram quinze anos juntos. Bígamo, ele rompeu o relacionamento para ficar apenas com sua mulher mais nova, com quem já tinha outro lar e filhos. Essa foi a única relação de longa duração que Joana teve na vida. Consolidou-se depois dos 40 anos, quando ela decidiu "sossegar" e "dar um pai" a seu filho, já que o progenitor era um "boçal". Disse ela certa vez em uma entrevista a mim:

Quando eu tive o meu filho, eu quis corrigir a minha vida. Eu não queria que o meu filho tivesse uma mãe prostituta, uma mãe vagabunda. Procurei um homem que fosse viver comigo e fosse o pai do meu filho. Eu me transformei na mãezona que sou. Na mãe, na esposa, na filha.

Dessa forma, acompanhada da experiência de morar sozinha e de estar um pouco "esquecida" por seu filho único, Joana ainda passou a ser tratada pelos vizinhos tal como na adolescência ou mesmo antes de se casar. Fonseca $(2004$, p. 32) diz que uma mulher sem marido pode perturbar a paz de uma comunidade porque desafia a virilidade dos homens e atiça os ciúmes das mulheres. Para evitar isso, precisam manter certa modéstia. A velhice pode boicotar essas tensões e garantir o recato, já que no imaginário social está ligada à assexualidade; mas esse não é o caso da 
chacrete. Ela gosta de sentir-se desejada, "sai bonita" pela rua e paquera mesmo os homens, principalmente os mais novos. Isso ela confessa a qualquer um, inclusive em muitas de nossas entrevistas gravadas.

Eu não gosto muito de velho, não. Eu não gosto de velho. Eu estou velha, não sou mais jovem. Só porque eu estou com essa idade, eu tenho que arranjar um homem de 80, 90 anos? Eu não! Eu gosto de 20, 22, 23, 24 anos. Eu falo assim: eu gosto, mas nunca fiz sexo com rapazes jovens. Eu paquero só, só olho. Garotão, eu paquero mesmo! Paquerar é paquerar, não é transar.

Bochichos, comentários e fofocas sobre a reputação de Joana voltaram à tona com o intuito de controlar seus comportamentos pouco modestos "para alguém de sua idade". É claro que ela evita a explicitação de seus afetos, procura uma certa discrição, mas também não castra seus desejos imediatos. "Velha esclerosada" e "safada" são xingamentos constantes.

Exageradamente ou não, os conflitos de Joana permitem-nos constatar que estar sozinha denuncia aos outros uma inabilidade da chacrete para as trocas afetivas e a manutenção de vínculos estáveis com o gênero oposto, algo condenável para uma mulher, segundo os parâmetros daqueles com quem convive. Dessa forma, quando Wood (1986, p. 189) afirma que o sentimento de solidão baseia-se em uma persistente "sensação de separação do outro", a autora abre-nos uma brecha para pensarmos que existe uma via de mão dupla, marcada por uma questão de gênero, nessa experiência de Joana. A chacrete solitária não só não compreende os demais ao seu redor e deles se afasta como também não é por eles compreendida. Ressentimentos e frustrações emocionais sempre emergem quando apenas um desses lados procura o distanciamento.

A solidão aparece, no entanto, nesse caminho de duas vias opostas, que não se querem próximas. Ambos os lados preterem-se, fogem de si. Pais (2006, p. 66) também acredita nessa dupla via da solidão: "Um sentimento de não pertença ao mundo, de abandono e desvinculação, muitas vezes é a dita 'sociedade' que lhe vira as costas, em uma 'renúncia' feita de 'derrotismo', 'quietismo', 'resignação”, A princípio, a solidão de Joana parece algo idiossincrático, um mero afastamento do mundo por conta de picuinhas de uma mulher "perturbada". Mas a análise da gramática de suas emoções revela algo eminentemente social em sua solidão, uma resposta do mundo à sua maneira de ser também. Joana sofre e encapsula-se por conta de problemas nos relacionamentos com as mulheres, por desavenças com os controles locais sobre seus comportamentos afetivo-sexuais não hegemônicos e por se sentir a todo instante ofendida. Segundo Wood (1986, p. 190), although people sometimes talk about loneliness in connection with 'non-social' events, (...), it turns out that what is actually involved is the lack of opportunity to commiserate with another, to share the experience. Thus, lonelinessisparadoxically more social thanother 'emotion'.

\section{"Acabei no final das contas sozinha"}

No entanto, nunca me pareceu que são as mulheres a maior motivação da "sensação de separação do outro" de Joana. Afinal, fofocas femininas, ela ouviu a vida toda. Sabe lidar muito bem com elas. Porém, as acusações denunciam sua incapacidade de ter estabelecido uma única relação amorosa conforme os ideais de "amor romântico" e "para sempre" ao longo de seus 60 anos (aquilo de que muitas mulheres a culpam e pelo que, de certa forma, também se sente mal). Uma frase muito dita por Joana nunca me saiu da cabeça, por ser o núcleo duro de toda a experiência de solidão e desencantamento com o mundo que ela vivencia nos últimos anos: "Fui uma mulher de muitos homens, mas acabei no final das contas sozinha". Nesse sentido, são os relacionamentos amorosos que provocam seus maiores sofrimentos, tornando-a melancólica, soturna, desacreditada. Sua solidão tematiza primordialmente a ausência, bem como o afastamento dos afetos masculinos na velhice.

Ser "abandonada pelo marido" com quem ficou durante 15 anos foi doloroso para Joana. Quando narra sofrimentos decorrentes da solidão, as lembranças dessa relação acompanham suas confissões. Dessa comunhão, costuma falar com um tom crítico. Aos 40 anos de idade, passou a viver com ele, um pouco mais jovem que ela. Para a relação ir adiante, foi preciso submeter-se a inúmeras imposições, como sair pouco à rua e acabar com qualquer atividade artística. Além disso, precisou fechar os olhos para inúmeras amantes, uma delas, inclusive, com quem ele dividiria outra casa e teria filhos. Foi esse companheiro mais duradouro de Joana quem criou seu filho único.

Reproduzo abaixo um longo trecho de uma entrevista gravada que fiz com Joana, em que ela transforma em palavras suas experiências de solidão. Durante a entrevista ela estava em seu sofá-cama, de onde costuma pouco sair quando está em casa. Confessar essas histórias de amores fracassados é sempre muito doloroso para a chacrete, mas, ao mesmo tempo, traz uma sensação de satisfação misturada a alívio. Tanto que muitas vezes nossas conversas íntimas pareciam ter como finalidade uma tentativa de "tratamento" por parte da chacrete. Sempre estive a postos para 
ouvir Joana confessar seus sentimentos. Isso porque contar a vida por meio de uma narrativa confessional pode ter uma "função de libertação" (Sayad, 1998, p. 233) àquele que declara.

Retomando também o clássico argumento foucaultiano da confissão como uma das técnicas ocidentais modernas mais eficazes na produção de verdades sobre os sujeitos (Foucault, 1988, p. 67), percebia em Joana um interesse de, por meio desse tipo específico de narrativa, produzir uma verdade sobre si mesma e, principalmente, para si mesma, verdade esta que pode lhe trazer algum efeito prático, de controle de sua situação e reunião em suas próprias mãos dos elementos dispersos e desconfortantes de uma vida tão dilacerada. O trecho que segue é emblemático dessa "função de libertação" de certas confissões sobre a solidão feitas por Joana a mim.

Mas um dia eu ainda quero ter um grande amor. Será que eu ainda vou ter? É tão difícil porque nenhuma de nós chacretes... Eu conversei com a Claudete. Nós estávamos conversando antes dela morrer. Nós éramos muito amigas. "Por que as chacretes não foram felizes?" Eu acho que foi até praga. As chacretes não foram totalmente resolvidas. Assim, você pegou alguma casada? Não pegou. É sempre assim. Sozinha ou sem ninguém. Eu acho que a nossa vida teve muita influência para a gente não ficar com ninguém. Eu, principalmente, não tive sorte. Mesmo com toda coisa, eu me sinto sozinha. Eu mesmo com alguém eu me acho só. Ser chacrete não teve um bom sucedimento. Assim, de casar, ser feliz, ter alguém, essas coisas. Eu era para estar muito bem casada. Porque eu só tive homens bons partidos. Não fiquei com ninguém. Não foram eles, não! Fui eu! Eu me adaptei para ter uma vida assim. Agora, por quê?? Porque eu não sou uma mulher que encare um casamento, que seja para sempre, que eu procure ser feliz. Não! Não! Entendeu? Eu queria ser feliz com alguém. Mas eu não encontro esse alguém. E no final eu me torno o quê? Solitária. Às vezes, quando eu saio... Quando eu acabo de fazer uma peça de teatro, eu saio, sabe? Quando eu olho pra fora e vejo... Meu Deus, não tem ninguém me esperando! Não tem ninguém que se importa comigo. Isso é muito ruim. Eu queria chegar em casa e meu marido perguntar: "Como é que foi sua peça, meu amor?" Aquela coisa toda de casal! Mas não. Eu só encontro solidão. É verdade mesmo. Eu só encontro a solidão. Mas, talvez, eu devo ter escolhido pra mim isso. Porque en nunca quero me apegar a ninguém. Então, a culpa deve ser minha mesmo, não é? Às vezes ele não entende a sua vida. Quer prender você. Não deixa você fazer o que quer. Quer proibir. Eu não sou mulher que homem me proíbe nada! Mas eu sou de família cigana também. Eu sou uma andarilha da vida e do amor. Eu sinto isso em mim, eu sinto que eu sou assim. Não sou para me prender a homem nenhum, não. Eu tenho um medo de me prender. Eu sigo muito a lei dos ciganos. Só se um dia eu encontrar um cigano pra mim. Aí vai ser diferente [risos]. Agora, quando chacrete, eu sempre tinha alguém me esperando lá fora! [risos]. Eu namorei muito artista. Até se dava bem, mas eu nunca consegui ficar com ninguém. Porque você ficar com alguém é a mesma coisa de você não ter ninguém. Fica ficando, passando o seu tempo para não ficar sozinho. Mas eu queria ter um amor sim, mas esse amor pra mim já chegou e foi embora. A banda passou e levou. Mas a vida é essa. [Interrupção para um café. Quando retomamos a gravação, Joana volta logo ao mesmo assunto, sem eu fazer qualquer pergunta] Eu gosto de ser livre. Pra mim liberdade é isso. Porque quando a gente, quando eu encontrei esse rapaz há muitos anos [ex-marido, de quem conversávamos no café], vivi com ele 15 anos. Eu fiquei presa ali. Levava tantos chifres. Ele tinha tantas mulheres! Eu sempre aceitei ele com a mulher. Mas ele não aceitava a vida que eu tinha. Ele me tirou das coisas que eu queria voltar. Pra eu aprender a estudar teatro foi muito difícil. Eu tinha que fazer tudo o que ele queria porque senão ele não deixava fazer as minhas aulas de teatro. Eu ainda era uma mulher muito bonita. Eu tinha muitas chances. Eu poderia fazer até Playboy! Ele foi no forró, encontrou uma mulher, do tipo dele. E ele foi viver com ela. E en fiquei feliz! Você não imagina quando ele falou pra mim: "Joana, eu tenho uma família!". "Você tá feliz, meu amor?”. "Ah, eu estou feliz!". "Então vamos arrumar as suas coisas e vai embora". Foi só felicidade! Quando ele foi embora e saiu pelo portão, eu dei um pulo e disse: "Meu Deus, eu estou livre”. Graças a Deus! E passamos a ser amigos. Quando ele morreu, ele estava já com a mulher dele. Ele teve um filho de 7 anos. Mas eu nunca tive raiva dele porque ele me deixou. Pelo contrário! Eu fiquei tão feliz porque ele estava me deixando. Porque eu poderia seguir a minha carreira. Eu falei assim: "O que adianta estar ao seu lado se eu me sinto tão só??" Ele fez bem encontrar uma mulher e ir morar com ela. Quando ele morreu, eu senti muito a morte dele. Ele estava tão feliz um dia antes. Ele teve infarto. Eu chorei muito! Mas foi com ele que eu sonhei também viver, viver uma vida legal. Com ele eu pensei que nós fôssemos ver os nossos netos juntos, ser feliz, mas também não deu! Acabou! Muitos casais não dizem, mas acaba. Aquele fogo, aquele tesão, com o passar dos anos, acaba. Não é a mesma coisa. Ainda mais eu, uma mulher que sempre gostei de se... hum, aventuras. Eu sempre gostei de aventuras, eu sempre gostei de sentir sensações, emoções. Então, ele tinha que ser feliz com outra mulher. Então eu dei essa oportunidade pra ela ficar com ele. Para ele ser feliz! Toda hora que ele ia embora, eu chorava. [Joana começa a chorar. Falas entrecortadas por choros. Tento acalmá-la e pergunto se não quer parar. Ela insiste em continuar]. Eu nunca deixei ele ver eu chorando. Ele ia me ver todo dia. Saber como é que eu estava. Quando ele ia embora, eu chorava, sim! Mas eu sabia que era melhor pra mim. Porque eu tinha escolhido a minha vida. Eu tinha escolhido o palco. Quer dizer então, hoje em dia eu sou casada com o palco. Mas en ficava triste quando ele ia embora. Eu só sei que ele morreu e eu senti muito a morte dele. Mas num dia eu pensei em ficar com ele, até que a morte nos separasse. Que a gente pudesse ficar 
velhinho nós dois! E fazer compras juntos no supermercado! [choros compulsivos] Mas não deu! Porque eu não tenho nada pra oferecer, nada pra dar. Não tenho mesmo não! Foi como eu falei praquela pessoa [uma "paquera” recente]. "Isso aqui é uma miragem. Não se apega a mim não, tá? Porque eu não vou ficar com você". Ele falou assim: "Joana, eu queria namorar com você!”. Eu falei: "É mesmo?”. Ele: "É!”. "Que tal a gente sair, a gente vai pra pracinha. Vamos tomar um caldo de cana com pastel?” Eu não sou mulher de pastel e caldo de cana! Eu ri, sabe? Eu não ri perto dele, não. Como é que eu vou sair com um homem pra comer um pastel e um caldo de cana? Ai, gente! Pra mim não dá. [risos]. Pra mim, eu tenho que sair e tomar um coquetel de frutas. Comer uma lagosta! Mas é assim mesmo! Mas é engraçada a minha vida. Alguém escuta essas coisas que eu falo pra você, alguém escuta? [Não, por enquanto só eu mesmo (risos)] Ah, você deve achar que eu sou muito doida, né? [risos]

"Por que as chacretes não foram felizes?" é uma pergunta que Joana traz consigo. É uma pergunta típica de quem dedica seus momentos a revisar a vida. Seu desejo é explicar o insucesso mediante a confissão de seus fracassos. Não o da fama, midiático. Mas o esquecimento oriundo das relações amorosas, de ter sido "deixada de lado pelos homens". São das impressões e recordações fugidias oriundas de um exame de si mesma que Joana constrói certezas fundamentais sobre e para ela própria. "Parece-nos, ao contrário, que a verdade, na região mais secreta de nós próprios, não 'demanda' nada mais que revelar-se" (Foucault, 1988, p. 69).

Joana formula respostas durante as entrevistas-confissões: o sofrimento advém de seus estilos de vida incompatíveis com o casamento, com a relação monogâmica, estável e fortemente marcada pela hierarquia. A culpa é dela, no final das contas, e não das "fraquezas masculinas", como em algumas narrativas da queixa em torno da violência doméstica, em que as virtudes femininas são invioláveis e inquestionáveis perante a incapacidade dos companheiros agressores (Gregori, 1993, p. 142). "Não foram eles não! Fui eu! Eu me adaptei para ter uma vida assim", disse Joana no trecho anteriormente citado. Já ouvi outras expressões entre as chacretes para se referirem a esse incômodo no campo amoroso confessado por Joana, tais como "mandiga", "olho gordo" e "maldição". Todas fazem referência a esse estado generalizado de solidão que marcaria o crepúsculo da vida dessas deusas do rebolado e que seria, pelo menos em uma primeira instância, provocado por elas mesmas. Quando Joana fala de "praga", o termo serve para remeter a uma ideia de condicionamento, algo indesejável, porém difícil de fugir e que domina a vida. Os termos apocalípticos apontam para uma perspectiva de culpas e punições.
O que tais narrativas nos esclarecem também é que se sentir solitária não é apenas se perceber vítima de um infortúnio como a morte de entes queridos e a ausência de amigos ao lado. Essa talvez fosse uma solidão menos questionável, decorrente de "causas externas”, digamos assim. A experiência sentimental da pessoa solitária é bastante complexa e ambígua, pois abre brechas para uma maior agência do sujeito. Um dos incômodos de Joana é justamente o fato de ela própria cooperar na produção de seus sentimentos de solidão. Têm-se consciência do mal, mas é difícil revertê-lo.

Casar, ter filhos, cuidar de um lar e viver eternamente ao lado de um único homem no âmbito do casamento são projetos de vida de longo prazo geralmente mencionados por Joana como os rumos certeiros para a felicidade de qualquer mulher. Mas quem disse que eles são desejáveis ou fáceis de serem praticados? Nunca houve entre as chacretes qualquer questionamento sobre esses padrões ideais, que acreditam ser corretos, mesmo que necessariamente não os tenham seguido à risca, ou pelo menos tentado. O que as lamúrias e experiências de solidão de Joana e outras chacretes nos mostram é que, apesar de esses planos comporem suas visões de mundo, eles em muitos casos eram incompatíveis com outras vontades e interesses delas, como gostar de namorar bastante, de ser artistas, de não "se sentirem presas", de "viverem na rua” etc. Saber conciliá-los, tornar vivências tão discrepantes e ambíguas compatíveis entre si foram algumas batalhas travadas por muitas. Algumas conseguiram uma medida comum, outras não. Estas carregam consigo o peso das "pragas" e das "maldições" nas costas quando se deparam com o fracasso dessa empreitada de conciliar autonomia feminina com relações conjugais englobantes.

Perceber-se, todavia, como alguém que destoa das pessoas ao redor favorece a emergência de um conjunto de vantagens que nenhuma chacrete nega; ao contrário, todas prendem-se a ele como justificativas de suas atitudes. Percebemos isso na ode que Joana faz à liberdade e independência feminina: "E eu nasci para ser livre, mesmo que isso me magoe no coração". Tais dilemas emergem porque há um imenso valor dado à "autoafirmação" (Duarte; Gomes, 2008, p. 254) feminina em certos momentos da trajetória de vida de boa parte das chacretes. São essas as fronteiras cujas arestas tornam-se quase sempre incompatíveis: ser livre, fazer o que se deseja ou se submeter a um homem, se sentir presa e comandada por ele. Tais aparentes contradições entre culpar-se e vangloriar-se, na verdade, seriam marcas indeléveis de trajetórias de vida que primam por não serem hegemônicas, comuns, banais.

Sayad (1999) diria que seriam os "paradoxos" ou "efeitos" de vidas extremamente desenraizadas e afe- 
tadas por experiências que reconfiguram seu cotidiano de tal forma que geram custos sociais que devem ser "pagos", principalmente por meio de demandas emocionais que podem chegar ao desespero ou a sua expressão patológica, como a depressão. Isso faz com que muitos indivíduos, em seus atos e discursos, queixem-se ou alegrem-se ao mesmo tempo de suas próprias vidas ou, nas palavras do autor, pôr-se-iam "ora a deplorar, ora a elogiar sua condição" (Sayad, 1999, p. 225).

\section{Algumas reflexões sobre a solidão de uma "cigana"}

A partir das confissões de Joana, sua experiência de solidão parece-nos ser sempre consequência de suas próprias ações, algo quase da ordem do idiossincrático, e, por isso, tantas autoacusações de incompetência amorosa. Há inflexões geradas pela sensação de culpa de que o "problema" estaria nela, em sua personalidade. No entanto, seguindo as propostas de uma gramática da solidão apresentada por Elias (2001, p. 75) em seu estudo sobre os moribundos, poderíamos constatar também algo mais relacional nesse sentimento. Para o autor, a solidão possui um amplo espectro, referindo-se em muitos casos a pessoas como Joana, cujo desejo de amor em relação aos outros foi muito cedo tão ferido e perturbado que, mais tarde, dificilmente puderam reviver a experiência sem sentir os golpes anteriores recebidos, sem sentir as dores a que esses desejos amorosos a expuseram em outros tempos. "Eu tenho um medo de me prender", costuma confessar. Suas dificuldades de amar mostram-nos muito mais do que uma incompetência pessoal, um temor do vínculo pelo mero apreço irreparável à liberdade. Eles revelam seus traumas diante de relações fracassadas e tristes, expõem seus grandes investimentos emocionais no passado em homens que, depois de tudo, simplesmente foram embora. Como conseguir ter "apego" a alguém hoje diante de tantas decepções? Será que amar não seria trazer de volta tudo de novo?

A valorização da liberdade é uma resposta de Joana a vivências ruins ao lado de muitos homens. Tanto que ela confessa hoje felicidade diante de um momento reconhecidamente frustrante, que gera choros e comove sempre. Elias (2001, p. 75) nos diz que, mesmo involuntariamente, pessoas solitárias afetadas por passados traumáticos costumam ocultar seus sentimentos diante dos outros ou mesmo fugir deles. As metáforas de uma vida cigana às quais Joana faz alusões em suas confissões são emblemáticas dessas tentativas de encontrar caminhos diferentes diante desses golpes amorosos do passado. Por que não conhecer um homem também livre, que não se fixe, não se prenda, seja um "andarilho da vida e do amor"? Talvez essa figura mítica e positiva do cigano seja aquela mais capaz de fazer frente a suas recordações de feridas e golpes provocados por relações amorosas tortuosas, porém ainda presentes em sua memória que de tão vivas a impedem de ir adiante e a fazem uma mulher solitária. A solidão é um mal menor, sentimento preferível às prováveis dores que é ter um homem ao lado.

Confessar a solidão a alguém é também desafiá-la. Joana sempre foi corajosa e sua solidão foi constantemente narrada, declarada abertamente, nunca escondida de mim nem dos mais próximos durante toda pesquisa de campo. O gravador nunca foi inimigo dos segredos, mas seu fiel escudeiro. A narrativa confessional, por mais íntima e delicada que nos pareça à primeira vista por ter justamente essa dimensão do segredo, do privado, garante ao mesmo tempo a possibilidade de reformulação da "verdade" do sujeito que a emite. "Um ritual onde a enunciação em si, independentemente de suas consequências externas, produz em quem a articula modificações intrínsecas: inocenta-o, resgata-o, purifica-o, livra-o de suas faltas, libera-o, promete-lhe a salvação" (Foucault, 1988, p. 71). Assumir ser solitária, sofrer abertamente pela falta de amor é sem sombra de dúvidas o reconhecimento público de Joana de seu próprio fracasso. Ao mesmo tempo, é liberar-se dele, explicitamente procurar por uma "salvação", como nos diz tão bem Foucault, ou produzir a "linguagem de verdade" que podemos ter sobre nós mesmos, esclarece Sayad (1999, p. 134).

Talvez fosse eu quem mais se sentia desconfortável com tantas revelações e entregas da "nativa", como se aquele nível de exposição fosse exigências provocadas por um pesquisador um tanto inescrupuloso e interessado em suas intimidades mais secretas, em fuxicar e remexer lembranças traumáticas. A chacrete gostava de falar de sua solidão na velhice aos mais próximos e narrar suas culpas e angústias. Ela encontrou na pesquisa uma maneira também de enunciá-las a quem queira ouvi-las e no pesquisador, alguém de extrema confiança e, por que não, um amigo.

Tudo acontece como se o autor da confidência tivesse encontrado naquele novo confidente uma nova pessoa com quem compartilhar seu segredo, sua carga, sua vergonha, sua maldição, o pesado fardo que o impede de 'ficar ereto' (tanto moral quanto fisicamente) e também o seu silêncio. O círculo dos confidentes aumentou. Um tabu caiu! (Sayad, 1999, p. 134)

Joana deseja claramente que pudesse ser jovem de novo para consertar hoje as atitudes que considera 
como sendo erradas. É o que chama constantemente de "vida errada", "leviana", "bandoleira”, "volúvel". Ao passado, Joana apega-se para confortar-se, mas também se afasta a fim de criticá-lo e impugná-lo. Nele parece existir um "mal" que a corrói e a impossibilita de dar um sentido mais positivo à sua existência. Gregori (1993, p. 185) defende que a enunciação confessional sempre tematiza a culpa e promove no narrador uma espécie de constante averiguação interna, um movimento de interiorização e expiação em que aquilo que é confessado recai exclusivamente como um fardo nas costas do próprio enunciador. Sayad (1999, p. 115) propõe ser isso o "sentimento de pecado" do confessor, bem recorrente nas narrativas de Joana ao relembrar a juventude. Ela inclina-se em um retorno sobre si mesma, que a leva a uma introspecção minuciosa, mas ao mesmo tempo suspeitosa, acusatória.

Joana quer descobrir o "pecado" em todo lugar e em todos os atos da vida pregressa, até chegar àquele considerado original, o primeiro, que engendrou numa cadeia de causas e consequências todos os outros menores, pontuais, "que não passam de atualizações do pecado original” (Sayad, 1999, p. 195). "É uma existência feita de consciência pesada, de suspeita, de culpa: uma existência 'envenenada' pelos lamentos e queixas - os que dirigem aos outros, os que dirigem a si mesmos" (Sayad, 1999, p. 228). A origem de todo o seu sofrimento situa-se em suas narrativas da solidão na vida liberal juvenil, que a afastou da família, e, principalmente, da realização pessoal por meio de um casamento estável e longevo. Vida essa que a aproximou da rua e suas falsas promessas de felicidade. É lá que mora o seu problema maior, por isso, há a obsessão de retorno ao passado, para reverter o erro e se estabelecer um mínimo de equilíbrio sentimental. Como isso não é possível, resta a ela uma constante sensação de culpa e autoagressão que em muitos momentos - não todos - leva a chacrete a uma introspecção melancólica e bastante sofrida. "Agora é um pouco tarde", confessa resignada a velha Joana, aceitando de vez a sina por ela mesma tecida.

\section{Referências}

ABU-LUGHOD, Lila; LUTZ, Catherine. Introduction: emotion, discourse and the politics of everyday life. In: LUTZ, Catherine; ABU-LUGHOD, Lila (Eds.). Language and the politics of emotion. Cambridge: Cambridge University Press, 1990.

ALVES, Andréa M. A dama e o cavalheiro: um estudo antropológico sobre envelhecimento, gênero e sociabilidade. Rio de Janeiro: FGV, 2004.

BISPO, Raphael. Gênero e carreiras artísticas na emergente indústria cultural brasileira. Comunicação e Sociedade, v. 21, p. 79-94, 2012.

Senhoras do rebolado: carreiras artísticas e sensibilidades femininas no mundo televisivo. Tese (Doutorado em Antropologia Social) - Universidade Federal do Rio de Janeiro, Rio de Janeiro, 2013.

CARADEC, Vincent. Vieilliraprès la retraite. Paris: PUF, 2004.

DEBERT, Guita. A reinvenção da velhice. São Paulo: Edusp, 1999.

DEBERT, Guita; BRIGEIRO, Mauro. A erotização da velhice. In: $36^{\circ}$ ENCONTRO ANUAL DA ASSOCIAÇÃO NACIONAL DE PÓS-GRADUAÇÃO EM CIÊNCIAS SOCIAIS, (21/10/2012 a 25/10/2012), Águas de Lindóia, SP, 21 out./ 25 out. 2012. (Exposição oral)

DUARTE, Luiz F. D.; GOMES, Edlaine de C. Três famílias: identidades e trajetórias transgeracionais nas classes populares. Rio de Janeiro: FGV/Finep/CNPq, 2008 .
FONSECA, Claudia. Família, fofoca e honra: etnografia das relações de gênero e violência em grupos populares. Porto Alegre: Ed. UFRGS, 2004.

ELIAS, Norbert. A solidão dos moribundos. Rio de Janeiro: Jorge Zahar, 2001.

FOUCAULT, Michel. A história da sexualidade 1: a vontade de saber. São Paulo: Graal, 1988.

GOLDENBERG, Miriam. Coroas: corpo, envelhecimento, casamento e infidelidade. Rio de Janeiro/São Paulo: Record, 2008.

GREGORI, Maria F. Cenas e queixas: um estudo sobre mulheres, relações violentas e a prática feminista. São Paulo: Paz e Terra/Anpocs, 1993.

LINS DE BARROS, Myriam. Testemunho de vida: um estudo antropológico de mulheres na velhice. In: CAVALCANTI, Maria L.; HEILBORN, Maria L.; FRANCHETTO, Bruna (Orgs.). Perspectivas antropológicas da mulher 2. Rio de Janeiro: Jorge Zahar, 1981.

Autoridade e afeto: avós, filhos e netos na família brasileira. Rio de Janeiro: Jorge Zahar, 1987.

LUTZ, Catherine. Unnatural emotions: every day sentiments on a Micronesian atoll and their challenge to western theory. Chicago: University of Chicago Press, 1988.

LUTZ, Catherine. "Engendered emotion: gender, power and the rhetoric of emotional control in american discourse". In: LUTZ, C.; ABU-LUGHOD, L. (Eds.). Language and the politics of emotion. Cambridge: Cambridge University Press, 1990.

MARTINS, Isis R. "Só há solidão porque vivemos com os outros...": um estudo sobre as vivências de solidão e 
sociabilidade de mulheres que vivem sós no Rio de Janeiro. Dissertação (Mestrado em Antropologia Social) Universidade Federal do Rio de Janeiro, Rio de Janeiro, 2010 .

MOTTA, Flávia de M. Velha é a vovozinha: identidade feminina na velhice. Santa Cruz do Sul, RS: Edunisc, 1998. PAIS, José Machado. Nos rastos da solidão: de ambulações sociológicas. Porto: Ambar, 2006.

PEIXOTO, Clarice. Histórias de mais de 60 anos. Estudos
Feministas, v. 5, n. 1, p. 148-158, 1997.

. Imagem e envelhecimento: as fronteiras entre Paris e Rio de Janeiro. São Paulo: Annablumme, 2000.

SAYAD, Abdelmalek. A imigração ou os paradoxos da alteridade. São Paulo: Edusp, 1999.

THOMPSON, Paul; ITZIN, Catherine; ABENSTERN, Michele. I don't feel old: the experience of later life. Oxford: Oxford University Press, 1991.

\title{
Portraits of loneliness: sufferings and female moralities in old age
}

\begin{abstract}
During the years 1970, chacretes - a group of sexy dancers - were prominent on television. In our days, they have more than sixty years old. This paper examines the life trajectory of this first generation. The aim of this article intends to discuss these women's loneliness experiences. It can be said that this emotion is a constant theme in the literature devote to aging and, at the same time, almost absent. This paradox establishes itself, because, while studies of active life of older people, loneliness emerges as a topic without sufficient researches. Thus, this paper wants to contribute toward an ethnography of female loneliness in old age. Being alone only makes sense under certain social conditions, especially when there are some social difference markers, such as age, gender, sexuality and class, directly articulated to this emotional experience.
\end{abstract}

Key words: gender, sexuality, aging, loneliness, art world.

\section{Retratos de soledad: el sufrimiento y la moralidad de mujeres en la vejez}

\section{Resumen}

Durante la década de 1970, un grupo de bailarinas, las chacretes, ganó prominencia en la televisión. Este artículo examina la trayectoria de vida de la primera generación de estas mujeres, hoy en día con más de sesenta años. A partir de un estudio etnográfico, el objetivo es discutir sus experiencias de soledad. Se puede decir que tal emoción es un tema constante y, al mismo tiempo, casi ausente en la literatura sobre el envejecimiento. Esta paradoja se establece porque, mientras se valorizó la vida activa de la "tercera edad", la soledad surgió como un tema para ser enfrentado. Por lo tanto, en este trabajo se busca contribuir a una etnografía de la soledad femenina en la tercera edad. Estar solo tiene sentido en ciertas condiciones sociales, sobre todo cuando percibimos los marcadores sociales de la diferencia, como el género, la sexualidad y la clase, articulados a dicha experiencia emocional.

Palabras clave: género, sexualidad, envejecimiento, soledad, mundo del arte. 